\title{
Risk Factors of Malnutrition among Children under Five Year of Age in Mohamed Alamin Paediatric Hospital University of Bahri - Khartoum, Sudan
}

\author{
Dr. Siham Mohamd Osman Gritly ${ }^{1}$, Ahmed Mohamed Mohamed Albashir², Asma Bashir Ali Ibrahim ${ }^{3}$
}

Khartoum Sudan

\begin{abstract}
This study was conducted in Sudan Khartoum state, Omdurman locality, (Mohamed Alamin Paediatric Hospital) within the period of $7 / 2$ to $22 / 5 / 2015$. The objectives was to identify risk factors contributing to malnutrition among children less than five year and to identify immediate factors contributing to malnutrition. This study was based on WHO classification of child from 0-59 month weight for height (HFH <-3 z-score, Or MUAC $<115 \mathrm{~mm})$. With the interpretation of the MUAC in this study the weight for height of the majority is (<-3SD), a high percentage of children (66.7\%) had a MUAC of less than $<11 \mathrm{~cm}(110 \mathrm{~mm})$, showing severe malnutrition and (28.6\%) had a MUAC of between 11 and 12cm; indicating moderate malnutrition. The majority of mother were breastfeeding their children having an idea of beneficial toward breastfeeding. This is one of good practices among Sudanese mothers. Low family income were found to be major risk factor of malnutrition among children. The study concluded that the Malnutrition is more prevalent in male children between 1-2 year of age and the low family income were found to be main factor contributed to malnutrition among children less than five years.
\end{abstract}

Keywords: Malnutrition, developing countries, Nutrition knowledge, children under five years

\section{Background}

Sudan federal ministry of health (2014)[1] acknowledged that the percentage of malnutrition among child in Sudan has become higher than the global figures. The undersecretary of the ministry of health confirmed that half a million children in Sudan are suffering from chronic malnutrition, which means that one in each 20 Sudanese children is severely malnourished. Malnutrition continues to be a major problem among children under five, with $12.6 \%$ suffering from severe wasting and stunting respectively [2]. The researchers were interesting to find out the most risk factors and to identify social-economic factors which lead to the prevalence of under nutrition among children under five years of age

Based on WHO epidemiological criteria the prevalence of stunting and wasting are classified as very high throughout the states of Sudan [3]. On 5th September (2014) the UNICEF [4]revealed report indicates that "Severe wasting" affects five percent of the under-five population in Sudan as a whole. They stated that Malnutrition is a major health and social problem from which many people are suffering, particularly children. It affects almost 800 million people, $20 \%$ of all in the developing countries. It is associated with about half of all children death worldwide. In developing countries, it is secondary to insufficient or inappropriate food supplies or early cessation of Breastfeeding. In some areas, cultural and religious food customs may play a role. Inadequate sanitation further endangers children by increasing the risk of infectious diseases that increase nutritional losses and alters metabolic demands [5].

Additional factors are bottle-feeding, inadequate knowledge of proper child rearing practices and parental illiteracy. The most extreme forms of protein-energy malnutrition are kwashiorkor and Marasmus [6]. UNICEF's 2014 Chief of Nutrition in Sudan said that; Eastern and western Sudan has the highest malnutrition rate in the country. It is estimated that 30 percent of children below the age of five are moderately or chronically malnourished Throughout Sudan; an estimated 750,000 children suffer from Severe Acute Malnutrition each year.

\section{Literature Review}

Risk factor for illness and death, with Millions of young children being affected due to infections, poverty and inadequate diet. Malnutrition increases the risk and worsens the severity of infections [7]. Infants and young children are most affected by malnutrition as they have increased nutritional needs to support growth [8]. Undernourished children, as well as children with severe malnutrition, have a higher risk of dying than children with an optimal nutritional status [9]. The term "malnutrition" is usually used to describe PEM. The comprehensive term of PEM" is universally accepted and its severe forms are called "marasmus", "kwashiorkor" and "marasmic kwashiorkor" [10].

\section{Developing countries and malnutrition}

Developing countries are defined as those countries which based mainly on agriculture. The spread of infectious disease and macro- micro deficiencies are Prevalence's mainly due to socio-economical and geographical factors.

Globally, it was estimated that one in every three preschool children is malnourished WHO \&UNICEF 2011 [11] estimated that 165 million children under-five years of age were underweight, 101 million were stunted and 52 million were wasted Childhood malnutrition is influenced by multidimensional factors, these factors vary from biological, behavioral and environmental [11]. New estimates in "Levels and Trends in Child Mortality 2014" show that in 2013, 6.3 million children under five died from mostly preventable causes, around 200000 fewer than in 2012, but still equal to nearly 17000 child deaths each day[2]. 


\section{International Journal of Science and Research (IJSR) \\ ISSN (Online): 2319-7064}

Index Copernicus Value (2013): 6.14 | Impact Factor (2014): 5.611

The improvement of nutrition therefore, is the main prerequisite for the reduction of high infant and under five mortality rates, the assurance of physical growth, social and mental development of children as well as academic achievement

A study of school-age children from Developing countries found the overall prevalence of stunting to range between $48-52 \%$ with an overall prevalence of underweight between $34-62 \%$ notes that among school-age children stunting and underweight are more prevalent than wasting [12]

Protein-energy malnutrition (PEM) is not due to deficiency in a single nutrient, but is often a result of inadequate intake or poor utilization of the food. In addition frequent infections contribute to malnutrition. For a long period the focus was on lack of protein in the diet, however now it is generally accepted that the lack of energy in the food is a more important and common factor for development of PEM [13].Study in northern Sudan on PEM revealed that poor family income has been found as a risk factor for severe acute malnutrition [14].

\section{Nutritional status and breast feeding}

For decades it has been known that breast milk is the best nutrition for infants. Breast milk is cheap, easily available and provides all the nutritional needs of a baby up to six months of age. Some studies have found an association between prolonged breastfeeding and malnutrition, based on demographic and health surveys in 19 countries, has found that still breastfed children in countries outside sub-Saharan Africa were shorter and lighter than those no longer breastfed. This became apparent at 12-18 months of age[15].

\section{Nutritional status in relation to weaning}

According to international recommendation, six months old children need complementary food in addition to breast milk [16].A study of infant feeding practices in Malawi has shown that complementary feeding was introduced as early as 2.5 months and was seen as a risk factor for infant malnutrition [17].

\section{Poverty and malnutrition}

Although Sudan is rich in natural and human resources, $(77.5 \%)$ of the households surveyed in north Sudan were on or below the poverty line [18]. The UNDP (2005)reported that $75 \%$ of north Sudan population as poor. The majority $(80 \%)$ is concentrating in rural areas where $30 \%$ of them suffered from extreme poverty. Study conducted byBejon $\mathrm{P}$, et al. 2008 [19]in rural Kenya showed that the significant causes of malnutrition were found to be poverty, lack of breast-feeding and improper weaning.

\section{Illiteracy and Socioeconomic factor}

Lack of education, inadequate or inappropriate education Breeds illiterate or semi-illiterate individuals who easily Succumbs to superstitions, taboos and irrational beliefs about some food items [20]. A study conducted by Smith LC, Haddad L J, 2002 [21] showed that one of the significant causes of malnutrition was found to be illiteracy. Low maternal income and overcrowding were associated with higher prevalence of wasting. However no association was found between the source of drinking water or social class and malnutrition. Study done in northern Sudan revealed that poor family income has been found as a risk factor for severe and acute malnutrition [14].

Overcrowded and unsanitary Living conditions are closely linked to poverty [10]. Studies show that Environmental and social factors as well as hygiene habits are important risk factors associated with nutritional status, as reported by Ferrari et al, 1998 in São Paulo, Brazil [22].

Study conducted in a decertified area of Sudan - Alrawakeeb valley revealed that maternal education was found to be the strongest factor associated with malnutrition among under five children [23].

\section{Design, setting and methodology}

This study carried out on children less than five year of age at Omdurman locality in Mohamed Alamin Pediatric Hospital. The main focus of this study was to determine the risk factors contributing to malnutrition among under five of age children. Data was collected using a questionnaire. The questionnaire gathered information regarding background information on mother and child, (breastfeeding, weaning and dietary intake) also gathered information regarding to the socio-economic information and educational level of the mother, was also determined the nutrition information.

\section{Study Area and Period}

The study was carried out at Mohamed Alamin Pediatric Hospital in Khartoum state Omdurman locality (march to April (2015). the hospital were located eastern Omdurman with total area (7200) meter square with length 120 meter and width 60 meter. This hospital was established in 1986 by Mohammed alaminhamid it consisted from two floors includes ward of neonates, kwashiorkor and ward for diarrhea and other seven wards.

\section{Results}

\section{The results presented in tables}

Table 1: Gender distribution of children under five years attended Mohamed Alamin Pediatric Hospital in Khartoum state Omdurman locality

\begin{tabular}{|l|l|l|l|}
\hline \multicolumn{2}{|l|}{ Gender Distribution } & No & Percent \% \\
\hline \multirow{3}{*}{ Valid } & Male & 28 & 66.7 \\
\cline { 2 - 4 } & Female & 12 & 28.6 \\
\cline { 2 - 4 } & Total & 40 & 95.2 \\
\hline
\end{tabular}

Table 2: Socio-economic status of the studied groups

\begin{tabular}{|c|c|c|c|}
\hline \multicolumn{2}{|c|}{ Income } & No & Percent $\%$ \\
\hline Valid & Moderate income $>1000$ & 16 & 38.1 \\
\cline { 2 - 4 } & Weak <1000 & 24 & 57.1 \\
\cline { 2 - 4 } & Total & 40 & 95.2 \\
\hline
\end{tabular}

Table 3: Anthropometric measures; height distribution of child less than five years of age

\begin{tabular}{|l|c|c|c|}
\hline \multicolumn{2}{|c|}{ Height } & No & Percent\% \\
\hline Valid & $50-65$ & 15 & 35.7 \\
\cline { 2 - 4 } & $65-75$ & 19 & 45.2 \\
\cline { 2 - 4 } & $75-80$ & 6 & 14.3 \\
\cline { 2 - 4 } & Total & 40 & 95.2 \\
\hline
\end{tabular}




\section{International Journal of Science and Research (IJSR) \\ ISSN (Online): 2319-7064}

Index Copernicus Value (2013): 6.14 | Impact Factor (2014): 5.611

Table 4: Anthropometric measures; distribution of weight among children under five year:

\begin{tabular}{|c|c|c|c|}
\hline \multicolumn{2}{|c|}{ Weight } & No & Percent\% \\
\hline Valid & $3-4$ & 12 & 28.6 \\
\cline { 2 - 4 } & $5-6$ & 12 & 28.6 \\
\cline { 2 - 4 } & $6-8$ & 13 & 31.0 \\
\cline { 2 - 4 } & $9-13$ & 3 & 7.1 \\
\cline { 2 - 4 } & Total & 40 & 95.2 \\
\hline
\end{tabular}

Table 4: Anthropometric measures; frequencies of MUAC among the children under five years of age

\begin{tabular}{|c|c|c|c|}
\hline \multicolumn{2}{|c|}{ Muac } & No & Percent\% \\
\hline Valid & $<11 \mathrm{~cm}$ & 28 & 66.7 \\
\cline { 2 - 4 } & $11-12 \mathrm{~cm}$ & 12 & 28.6 \\
\hline
\end{tabular}

Table 5: frequencies of mother who are breastfeeding

\begin{tabular}{|c|c|c|c|}
\hline Mothers who breastfed their child's & NO & Percent\% \\
\hline \multirow{4}{*}{ Valid } & Yes & 26 & 61.9 \\
\cline { 2 - 4 } & No & 14 & 33.3 \\
\cline { 2 - 4 } & Total & 40 & 95.2 \\
\hline
\end{tabular}

Table 7: Weaning practices and reasons of stopped breastfeeding

\begin{tabular}{|c|c|c|c|}
\hline \multicolumn{2}{|c|}{ Weaning } & NO & Percent\% \\
\hline \multirow{3}{*}{ Valid } & before his first year <1 year & 15 & 35.7 \\
\cline { 2 - 4 } & after his first year 1-2 years & 25 & 59.5 \\
\cline { 2 - 4 } & Total & 40 & 95.2 \\
\hline
\end{tabular}

Table 8: Frequencies of health knowledge among the mothers

\begin{tabular}{|c|c|c|c|}
\hline \multicolumn{2}{|c|}{ did you heard about malnutrition disease } & No & Percent $\%$ \\
\hline \multirow{3}{*}{ Valid } & Yes & 15 & 35.7 \\
\cline { 2 - 4 } & No & 25 & 59.5 \\
\cline { 2 - 4 } & Total & 40 & 95.2 \\
\hline Total & & 42 & 100 \\
\hline
\end{tabular}

\begin{tabular}{|c|c|c|c|}
\hline \multicolumn{2}{|c|}{$\begin{array}{c}\text { did you follow-up health center for the } \\
\text { purpose of nutrition }\end{array}$} & No & Percent\% \\
\hline \multirow{3}{*}{ Valid } & Yes & 9 & 21.4 \\
\cline { 2 - 4 } & No & 31 & 73.8 \\
\cline { 2 - 4 } & Total & 40 & 95.2 \\
\hline
\end{tabular}

\begin{tabular}{|c|c|c|c|}
\hline \multicolumn{2}{|c|}{ did you get guides about child nutrition } & No & Percent $\%$ \\
\hline \multirow{3}{*}{ Valid } & Yes & 11 & 26.2 \\
\cline { 2 - 4 } & No & 29 & 69 \\
\cline { 2 - 4 } & Total & 40 & 95.2 \\
\hline
\end{tabular}

\begin{tabular}{|c|l|c|c|}
\hline \multicolumn{2}{|c|}{ if yes from where you get it } & $N O$ & Percent $\%$ \\
\hline Valid & health centers & 3 & 7.1 \\
\cline { 2 - 4 } & Hospitals & 3 & 7.1 \\
\cline { 2 - 4 } & Organization & 4 & 9.5 \\
\cline { 2 - 4 } & from media & 1 & 2.4 \\
\cline { 2 - 4 } & not received any guides & 29 & 69.0 \\
\cline { 2 - 4 } & Total & 40 & 95.2 \\
\hline
\end{tabular}

\section{Discussion}

Malnutrition was more prevalent in males than in females were found among children attended Mohamed Alamin Pediatric Hospital Khartoum Sudan. Studies in Ethiopia done by Christiaensen and Alderman (2001 [24]found that more boys than girls younger than five years old had malnutrition another study in Botswana found that malnutrition was more prevalent in males than in females under five years of age [25]. These studies therefore correlates well with abovementioned data, as a significantly higher percentage of males had malnutrition (66.7\%).Majority of family's monthly incomes were less than 1000SD $(57.1 \%)$.). And $(31 \%)$ of fathers were completed their secondary school and only about (11.9\%) completed the university. While mothers' were found to be (42. 9\%) basic education and only (7.1\%) higher education. Low income among the families might contribute very much to under-nutrition among their children. Study done in northern Sudan by Coulter JB, et al [14] revealed that poor family income has been found as a risk factor for severe acute malnutrition.

This study was based on WHO classification of child from 0-59 month weight for height $(\mathrm{HFH}<-3 \mathrm{z}$-score, Or MUAC $<115 \mathrm{~mm})$. With the interpretation of the MUAC in this study the weight for height of the majority is (<-3SD), a high percentage of children $(66.7 \%)$ Had a MUAC of less than $<11 \mathrm{~cm}(110 \mathrm{~mm})$, showing severe malnutrition and $(28.6 \%)$ had a MUAC of between 11 and $12 \mathrm{~cm}$; indicating moderate malnutrition. according to study in Kenya on children twelve to 59 months showed that the clinical features of malnutrition were significantly more common in children that had a weight for height of <-2 SD [26].

In a study done in Limpopo, South Africa, children were followed from birth up to three years of age and results showed that when a child has a greater height at one year it protects the child against stunting. Normal length and weight at one year are very important as this can predict the nutritional status of the child at three years of age [27].

The majority (61.9\%) of mother were breastfeeding their children and about $(95.2 \%)$ of mothers having an idea of beneficial toward breastfeeding. (38.1\%) of mothers were said breastfeeding is useful this finding is supported by study conducted by Farhia \& Fardows, 2010 [28]in Sudan and their finding was revealed that the majority of respondents were having an idea of beneficial toward breastfed. This is one of good practices among Sudanese mothers as the constituents of breast milk is very nutritious and contains antibodies and lymphocyte from the mother that help child resist infection.

\section{Conclusion}

The study concluded that the Malnutrition is more prevalent in children between ages one to two year. Low family income were found to be major risk factor of malnutrition among children. Educated mothers are more likely to give more nutritious food than their uneducated counterparts. Significantly more boys than girls in this study presented with malnutrition. Nutrition information received by the mother regarding basic information necessary to care for children was very low among most mothers.

\section{References}

[1] Sudan Federal Ministry of Health (2014)

\section{Volume 5 Issue 2, February 2016 www.ijsr.net}




\section{International Journal of Science and Research (IJSR) \\ ISSN (Online): 2319-7064}

Index Copernicus Value (2013): 6.14 | Impact Factor (2014): 5.611

[2] WHO, 2014Technical Note 1 Nutrition country profile indicators: Definitions and sources.

[3] WHO, 2013Global Database on Child Growth and Malnutrition

[4] UNICEF-WHO-The World Bank project

[5] Grigs by DG (2005). www.eMedicine, Malnutrition.

[6] Wong DL, Hockenberry M, Winkelstein ML, Wilson D, Ahmann E Philadelphia, London, 865-68.

[7] Müller, O. and Krawinkel, M. 2005. Malnutrition and health in developing countries, Canadian Medical Association Journal [Internet] August, vol. 173, no. 3. Available from: http://www.cmaj.ca [Accessed February 5th, 2007].

[8] Torún, B. 2006. Protein-Energy Malnutrition in, Modern Nutrition in health and disease. 10th ed. pp. 881-906. United States of America: Lippincott Williams \& Wilkins.

[9] Caulfield, L.E., De Onis, M., Blössner, M. and Black, R.E. 2004. Undernutrition as an underlying cause of child deaths associated with diarrhea, pneumonia, malaria and measles. American Journal of Clinical Nutrition. Vol. 80. pp. 193 - 198.

[10] Torún, B. and Chew, F. 1994. Protein-Energy Malnutrition in, Modern Nutrition in health and disease. 8th ed. Vol. 2. pp. 950 - 975. United States of America: Lea \&Febiger.

[11] WHO. (2012). 1990-2011 Levels and Trends in Child Malnutrition. World Health Organization.WHO-World Banks-UNICEF.

[12] Standing Committee on Nutrition. (2002, December). School Age Children their Health and Nutrition. SCN News (25), pp. 1-78.

[13]FAO, 1997 report

[14] Coulter JB,omerMI,sulimanGI,moody $\mathrm{JB}$, macfarlaneSB,HndrickseRG.protein

energy malnutrition in northern sudan :prevalence socioeconomic risk factor and family background. Ann trop paediatr.1988; 8(2):96-102.

[15] Caulfield LE, Bentley ME, Ahmed S. Is prolonged breastfeeding associated with malnutrition? Evidence from nineteen demographic and health surveys. Int $\mathbf{J}$ Epidemiology 1996;25(4):693-703. (Lonnerdal B. Breast milk: A Truly Functional Food. Nutrition Volume 16, Numbers 7/8, 2000.).

[16] King FS, Burgess A. Nutrition for Developing Countries. Oxford University Press, 2nd edition 2000.

[17] Vaathera M, Kulmala T, Hietanen A, et al. Breastfeeding and complementary feeding practices in rural Malawi. ActaPædiatric 2001: 90: 328-332.

[18] Sudan Household Health Survey (SHHS) and Millennium Development Goals (MDG) indicators (2006). Sudan.

[19] Bejon P, Mohammed S, Mwangi I, Atkinson SH, Osier F, et al. (2008) Fraction of all Hospital Admissions and Deaths Attributable to Malnutrition among Children in Rural Kenya. Am J ClinNutr 88: 1626-1631.

[20] Alade, IbukunOlu (2001), Public health Nutrition (2nd ed.) Ilori, S.O.A. Fosco Venture press.

[21] Smith LC, Haddad LJ (2002) Overcoming Child Malnutrition in Developing Countries. IFPRI series No. 64. Syed, S. A., Nasim, K., Abdulghaffar, B. \& Syed, (2005). S. H. Association of Literacy of Mothers with Malnutrition among Children Under Three Years of
Age in Rural Area of District Malir, Karachi. J Pak Med Assoc, 55(12), 550-553.

[22] Ferrari AA, Solymos GM, Castillo RM, Sigulem DM (1998) Risk factors for protein-energy malnutrition in pre-school shantytown children in São Paulo, Brazil. Sao Paulo Med J 116: 1654-1660.

[23] Ola E, Ahmed, Mofida Y, et al (2011) Nutritional status of the children under age of five in a decertified area of Sudan - Alrawakeeb valley. International Journal of Current Research 2: 103-108.

[24] Christiaensen, L. and Alderman, H. 2001. Child Malnutrition in Ethiopia: Can Maternal Knowledge Augment The Role of Income? The World Bank. [Internet] Available from:http://www.worldbank.org.za [Assessed January 7th, 2007].

[25] Mahgoub, S.E.D., Nnyepi, M. and Bondeke, T. 2006. Factors affecting prevalence of malnutrition among children under three years of age in Botswana. African Journal of Food, Agriculture, Nutrition and Development. Vol. 6. No. 1. pp. 1-15.

[26] Berkley, J., Mwangi, I., Griffiths, K., Ahmed, I., Mithwani, S., English, M., Newton, C. and Maitland, K. 2005. Assessment of severe malnutrition among hospitalized children in rural Kenya: comparison of weight for height and mid upper arm circumference. Journal of the Amerian Medical Association. Vol.294. No.5. Pp.591-7.

[27] Mamabolo, R.L., Alberts, M., Steyn, N.P., Delemarrevan de Waal, H.A. and Levitt, N.S. 2005. Prevalence and determinants of stunting and overweight in 3-yearold black South African children residing in the Central Region of Limpopo Province, South Africa. Public Health Nutrition. Vol. 8. nr. 5. pp.501-508.

[28] Farhia .A ,Fardows S, 2010.Assessment of therapeutic feeding practice for protein energy malnutrition among the child under five years of age /Ahfad University. sudankhrtoum state,Omdurman locality. 